\title{
Induction of interleukin 6 and interleukin 8 expression by Broncho-Vaxom (OM-85 BV) via $\mathrm{C}-\mathrm{Fos} / \mathrm{serum}$ responsive element
}

\author{
R Keul, M Roth, E Papakonstantinou, M Nauck, A P Perruchoud, L H Block
}

Division of

Pneumology,

Departments of

Internal Medicine

and of Research,

University Hospital

Basel, Hebelstrasse 20,

CH-4031 Basel,

Switzerland

R Keul

M Roth

E Papakonstantinou

M Nauck

A P Perruchoud

Department of

Medicine,

University of Vienna,

Währinger Gürtel 18-

20, A-1090 Vienna,

Austria

L H Block

Correspondence to:

Dr M Roth.

Part of this work was presented at the XVII World Congress on Diseases of the Chest, 13-18 June 1993 in Amsterdam, Netherlands, and the abstract published in and the abstract publish
Original Investigations Original Investigations
(Abstracts), page 199S.

Received 14 July 1994 Returned to authors Returned to authors Revised version received 3 January 1995

Accepted for publication

3 October 1995

\begin{abstract}
Background - Broncho-Vaxom (OM-85 $\mathrm{BV}$ ) increases the resistance of the respiratory tract to bacterial infections by modulating host immune responses. The compound increases serum IgG levels but decreases IgE levels in patients suffering from chronic bronchitis or chronic obstructive pulmonary disease. It increases concentrations of $\gamma$-interferon (IFN- $\gamma$ ), IgA, and interleukin (IL) -2 in bronchoalveolar lavage fluid of patients with bronchitis. Treatment with OM-85 BV increases the number of $T$ helper and natural killer cells. In this study the effects of OM$85 \mathrm{BV}$ on transcription of cytokines is investigated in human lung fibroblasts.

Methods - Transcription and synthesis of IL-6 and IL-8 were assessed in cultured primary human lung fibroblasts using standard methods of Northern blot analysis for the level of mRNAs and enzyme linked immunosorbent assay for proteins. Results - Broncho-Vaxom (OM-85 BV) at different concentrations induced transcription of IL-6 and IL-8. The effect of the drug on transcription of IL-6 and IL8 genes correlated with secretion of the proteins into cell supernatants. OM-85 BV-dependent expression of the interleukin genes involved C-Fos/serum responsive element (C-Fos/SRE).

Conclusions - The data suggest that the various immunopharmacological activities of OM-85 BV that have been described in clinical studies may be explained by its ability to induce expression of IL-6 and IL-8.

(Thorax 1996;51:150-154)
\end{abstract}

Keywords: immunomodulators, gene regulation, interleukin, lung fibroblasts.

Broncho-Vaxom (OM-85 BV; OM Laboratories, Geneva, Switzerland), a lyophilised extract of eight species of bacteria which are frequently associated with inflammation of the respiratory tract, has been shown to modulate cellular immune mechanisms leading to increased resistance against bacterial infections. ${ }^{1-3}$ Oral administration of OM-85 BV induces the production of antibodies against the various components of the immunomodulator. ${ }^{14}$ OM-85 BV increases IgG levels but decreases IgE levels in patients with chronic bronchitis or chronic obstructive lung disease. ${ }^{5-7}$ Furthermore, treatment with OM-85 leads to increased con- centrations of $\gamma$ interferon (IFN- $\gamma$ ), IgA, and interleukin (IL)-2 in bronchoalveolar lavage (BAL) fluid of patients suffering from bronchitis. ${ }^{6-10}$ Long term administration of the drug increases the number of $\mathrm{T}$ helper and natural killer cells but decreases the number of $T$ suppressor cells. ${ }^{6}$

In vitro studies have shown that $\mathrm{OM}-85 \mathrm{BV}$ induces the secretion of type $\mathrm{E}$ prostaglandins, tumour necrosis factor (TNF), and nitric oxide in isolated macrophages. ${ }^{10-12}$ The compound also stimulates the adhesion of human polymorphonuclear leucocytes to endothelial cells. ${ }^{1314}$ These effects suggest a pharmacological potency of the drug at various levels of the immune system; however, its exact mode of action remains unclear.

A number of activities of IL-6 and IL-8 suggest that these factors have a significant role in mediating inflammatory and immune responses. IL-6 displays various proinflammatory effects that are potentially relevant to inflammation of the airways, including its ability to stimulate proliferation of thymocytes and T cells, ${ }^{1516}$ to stimulate cytotoxic T lymphocyte differentiation, ${ }^{17}$ to upregulate IL-4 dependent IgE production, ${ }^{18}$ and to mediate the terminal differentiation and immunoglobulin production of B cells. ${ }^{15}$ In contrast, IL-6 has also been shown to diminish tissue inflammation in animal models of hypersensitivity pneumonitis, ${ }^{19}$ oxygen toxicity, ${ }^{20}$ and endotoxin-induced lung injury, ${ }^{21}$ and to inhibit macrophage production of IL-1. ${ }^{22}$ The proinflammatory effects of IL-8 are reflected by its ability to modulate the expression of various adhesion molecules in bronchial epithelial cells ${ }^{2324}$ and lung macrophages. ${ }^{25}$ IL-8 also augments production of protease by neutrophils, ${ }^{26}$ generation of oxygen radicals, ${ }^{27}$ and activity of 5-lipoxygenase in polymorphonuclear leucocytes. ${ }^{2829}$

Since IL- 6 and IL- 8 may be of importance in the inflammatory mechanisms associated with infection and immunity, we have characterised the effects of OM-85 BV on the expression of IL- 6 and IL- 8 in human lung fibroblasts. This cell is known to be involved in the immune response initiated by infection or injury of the lung. ${ }^{30}$ We have investigated the effect of Broncho-Vaxom on the transcription, translation, and secretion of IL- 6 and IL-8 in cultivated primary human lung fibroblasts.

\section{Methods}

CULTURE OF LUNG FIBROBLASTS

Five primary cell lines of fibroblasts were established from biopsy samples of human lung 


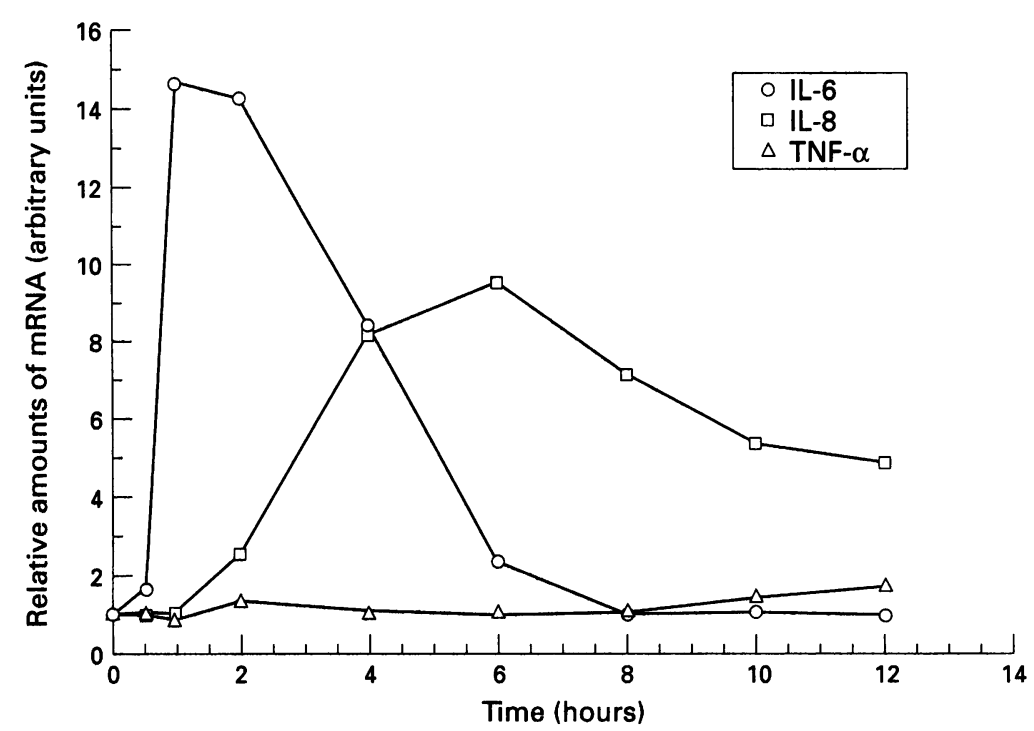

Figure 1 Kinetics of OM-85 BV-induced (10 $\mu \mathrm{g} / \mathrm{ml}$ ) transcription of $I L-6$ and $I L-8$ genes in human lung fibroblasts. Arbitrary units of $m R N A$ were calculated by computerised image analysis of Northern blots in relation to the constitutive HLA- $\beta$ gene. Each curve displays a representative analysis performed in one of the five primary cell lines of human lung fibroblasts; similar results were obtained with the other four cell lines.

tissue as described previously. ${ }^{31}$ Cells were cultivated in minimal essential medium supplemented with $10 \%$ fetal calf serum (FCS), $8 \mathrm{mM}$ L-glutamine, and $1 \%$ vitamin $\mathrm{mix}$ to an $80 \%$ subconfluent monolayer. Subconfluent cultures of the cells were kept in low serum medium $(0.5 \% \mathrm{FCS})$ for two days before stimulation with $\mathrm{OM}-85 \mathrm{BV}(0 \cdot 1-100 \mu \mathrm{g} / \mathrm{ml})$ for various time periods $(0,0 \cdot 5,1,2,4,6,8$, and 12 hours). All experiments were performed using cell lines in passages $1-4$.

\section{EXTRACTION OF TOTAL RNA AND NORTHERN} BLOT ANALYSIS

Total RNA was extracted by the guanidinium isothiocyanate method and analysed by Northern blotting. ${ }^{32}$ Hybridisation with radioactive

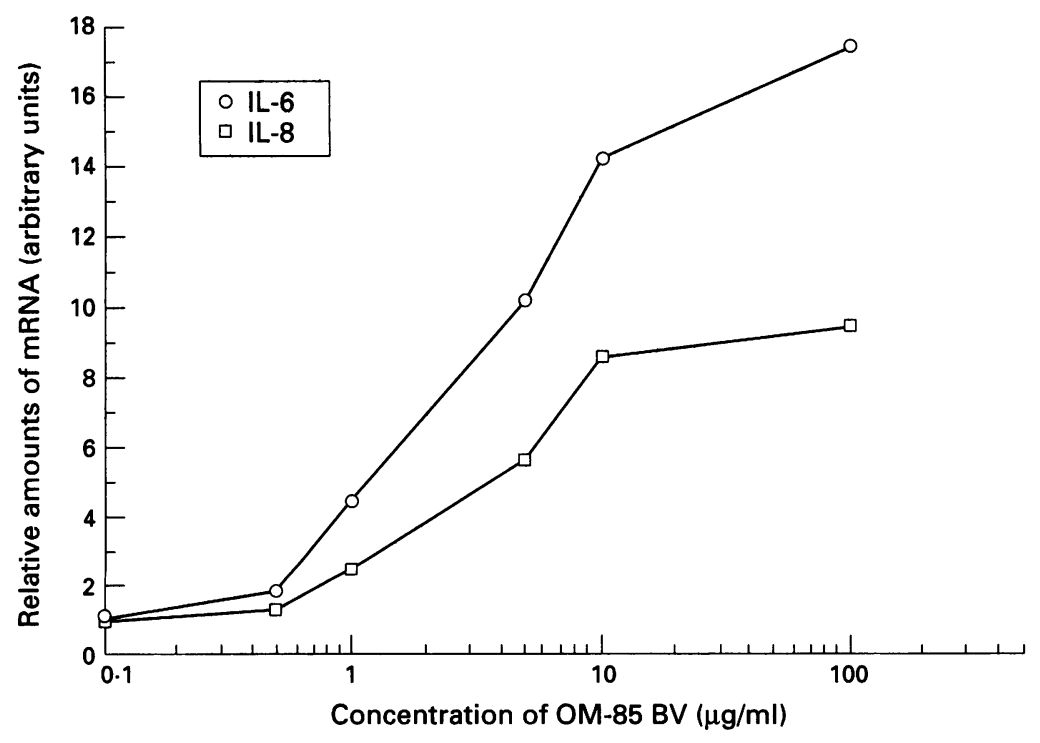

Figure 2 Dose dependence of OM-85 BV-induced transcription of IL-6 and IL-8 genes in human lung fibroblasts. The data represent the relative amounts of $m R N A$ for the two interleukins assessed at the time points of maximal transcription (IL-6 at one hour; IL-8 at six hours). Each curve shows one representative analysis done in one primary cell line of human lung fibroblasts; similar results were obtained with the other four cell lines. labelled oligonucleotides (IL-1 $\alpha$ to IL-10, GMCSF, M-CSF, and TNF- $\alpha$; British Biotechnology, Abingdon, UK) was performed overnight at $45^{\circ} \mathrm{C}$ (buffer: $1 \mathrm{M} \mathrm{NaCl}, 1 \%$ sodium dodecyl sulphate, $50 \%$ formamide, $10 \%$ dextran sulphate, $1 \mathrm{mg} / \mathrm{ml}$ sonicated heat denatured salmon sperm DNA, and $75 \mathrm{mg} / \mathrm{ml}$ polyethylene glycol 6000). The membranes were washed under sterile conditions. In brief, membranes were washed for 30 minutes at room temperature in $5 \times$ SSC buffer $(1 \times$ SSC: $0.156 \mathrm{M} \mathrm{NaCl}, 0.014 \mathrm{M}$ sodium citrate), then two washes in $1 \times \mathrm{SSC}$ at $55^{\circ} \mathrm{C}(15$ minutes), and a final wash in $1 \times$ SSC at room temperature (15 minutes). Membranes were then exposed to a radiographic film (X-Omat, Kodak, Geneva, Switzerland) for 48 hours at $-70^{\circ} \mathrm{C}^{32}$

TRANSLATION AND SECRETION OF IL-6 AND IL-8 OM-85 BV-induced de novo synthesis of IL-6 and IL- 8 proteins was tested in human fibroblasts. Quiescent subconfluent cultures were incubated for 12 hours in the presence of various concentrations of $\mathrm{OM}-85 \mathrm{BV}(0 \cdot 1$ to $100 \mu \mathrm{g} / \mathrm{ml})$. The cells were then scraped with a rubber policeman and sonicated on ice for 10 seconds (twice). The homogenate was centrifuged (five minutes, $10000 \mathrm{~g}, 4^{\circ} \mathrm{C}$ ) and the amount of the two interleukins was determined

\author{
c-fos
}
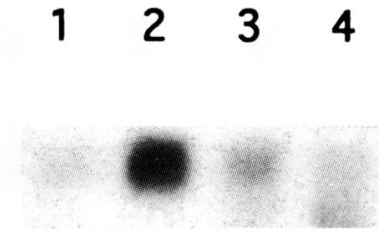

IL-8

TNF- $\alpha$

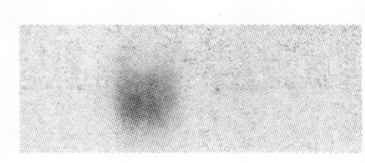

IL -6

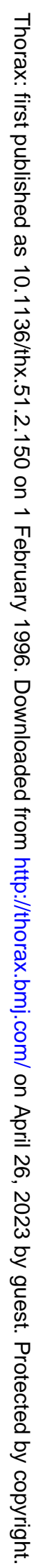

Figure 3 Northern blot analysis of the modulatory effects BV-induced transcription of IL-6 (at one hour), IL-8 (at six hours), TNF- $\alpha$ (at 12 hours), and c-fos (at 30 minutes) in human lung fibroblasts. Lane 1, unstimulated control fibroblast; lane 2, OM-85 BV (10 $\mathrm{gg} / \mathrm{ml})$; lane 3, OM-85 BV+DMSO (2\%); lane 4; OM-85 BV+ polymyxin $B(10 \mu M)$. Similar results were obtained with the remaining four cell lines. 

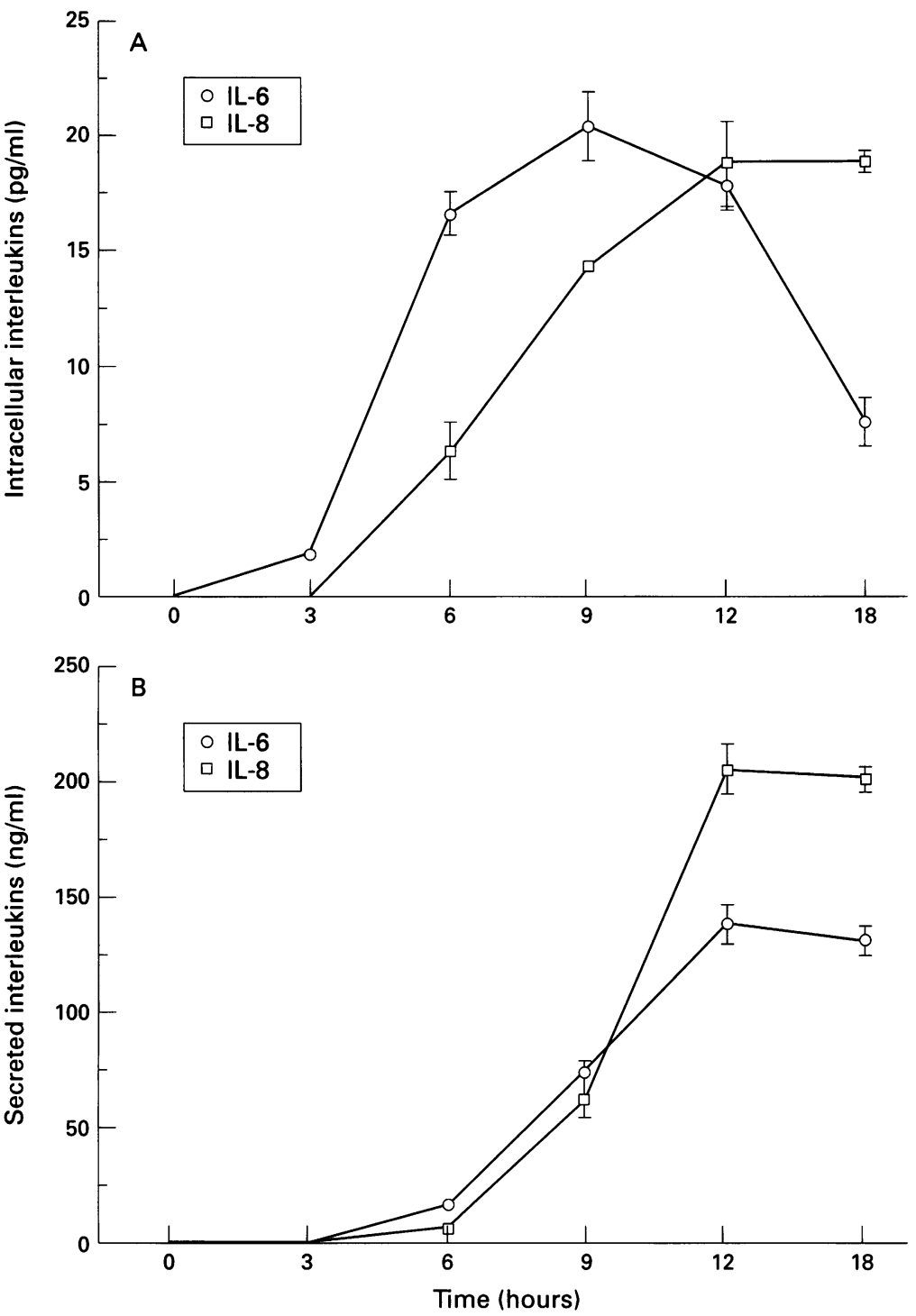

Figure 4 (A) Kinetics of OM-85 BV-induced $(10 \mu \mathrm{g} / \mathrm{ml})$ synthesis of intracellular proteins of IL-6 and IL-8 in human lung fibroblasts and (B) kinetics of OM-85 BVinduced secretion of IL-6 and IL-8 in human lung fibroblasts. Each time point represents the mean (SE) of five independent experiments.

in the supernatant by enzyme linked immunosorbent assay (EIA). ${ }^{33}$

To determine secretion of interleukins $100 \mu \mathrm{l}$ samples of culture medium were collected at $0,4,8$, and 12 hours and the amounts of proteins were assessed by EIA. All experiments were performed in triplicate with each cell line.

\section{TRANSCRIPTION FACTORS}

Dimethyl sulphoxide (DMSO) 2\% was used to determine the role of the C-Fos/SRE in OM$85 \mathrm{BV}$-induced gene activation. ${ }^{34}$ Following incubation of the cells for various times, RNA was extracted for Northern blot analysis or cells were continued in culture to determine secretion of IL-6 and IL-8.

To investigate the involvement of protein kinase C (PKC) in OM-85 BV-dependent activation of C-Fos ${ }^{3435}$ subconfluent cultures of cells were incubated with the PKC inhibitor polymyxin $B(10 \mu \mathrm{g} / \mathrm{ml})$ for 30 minutes before stimulation with the OM-85 BV.

\section{ENDOTOXIN ASSAY}

Contamination of OM-85 BV with lipopolysaccharides was excluded by means of a Limulus polyphemus lysate assay (EIA, Amersham, UK).

\section{Results}

Possible effects of OM-85 BV on the transcription of various genes encoding interleukins (IL-1 $\alpha / \beta$, IL-2, IL-3, IL-4, IL-5, IL-6, IL-7, IL-8, IL-10), colony stimulating factors (GMCSF, M-CSF, G-CSF), and tumour necrosis factor (TNF) $-\alpha$ were assessed in human lung fibroblasts. OM-85 BV specifically induced the transcription of two (IL-6, IL-8) of the 10 cytokines investigated and the transcription of TNF- $\alpha$. The transcription of IL-6 started 30 minutes after the addition of the drug, reached a plateau between 1-2 hours $(15 \times)$, and declined thereafter (fig 1), while the transcription of IL-8 started to increase two hours after the cells were stimulated with OM-85 BV and peaked at 4-6 hours $(9 \times)$. Only a slight increase of the mRNA signal for TNF- $\alpha(1.5 \times)$ was observed 12 hours after stimulation with $\mathrm{OM}-85 \mathrm{BV}$ (fig 1).

The induction of the two interleukins was dose dependent (fig 2) with $\mathrm{EC}_{50}$ values of $\mathrm{OM}-85 \mathrm{BV}$ in the range which can be obtained under therapeutic conditions. For all the following experiments an effective dose of $10 \mu \mathrm{g}$ $\mathrm{OM}-85 \mathrm{BV} / \mathrm{ml}$ was used.

The ability of OM-85 BV to induce transcription of the genes coding for the transcription factors C-Fos and C-Jun was investigated. While the drug induced transcription of the c-fos gene (fig 3), it failed to induce transcription of the c-jun gene.

Since activation of C-Fos requires the action of PKC, ${ }^{35}$ we further delineated the mode of action of $\mathrm{OM}-85 \mathrm{BV}$ on gene activation by incubating cells with polymyxin B $(10 \mu \mathrm{g} / \mathrm{ml})$. In the presence of this inhibitor of PKC the OM-85 BV-induced transcription of c-fos, as well as the transcription of the two cytokine genes and of the gene coding for TNF- $\alpha$, was abrogated (fig 3). In addition, OM-85 BVinduced transcription of activated genes studied was abolished in the presence of actinomycin $\mathrm{D}(5 \mathrm{mg} / \mathrm{ml})$ which suggests that the compound stimulates the de novo transcription of the respective genes (data not shown).

To evaluate the role of C-Fos/SRE on OM$85 \mathrm{BV}$-induced transcription of c-fos and the two interleukin genes we tested the effect of DMSO (2\%) which inhibits C-Fos/SRE. ${ }^{34}$ In the presence of DMSO the OM-85 BV-dependent transcription of c-fos was completely blocked (fig 3). Similarly, the transcription of IL-6, IL-8, or TNF- $\alpha$ stimulated by OM-85 BV was abolished in the presence of DMSO. DMSO alone did not affect the basal transcription of the genes investigated.

OM-85 BV induced an increase of both the intracellular expression of IL- 6 and IL-8 proteins (fig 4A) and their secretion. Maximal secretion of both cytokines was observed 12 hours after the addition of OM-85 BV to the culture medium (fig 4B). The OM-85 BV- 


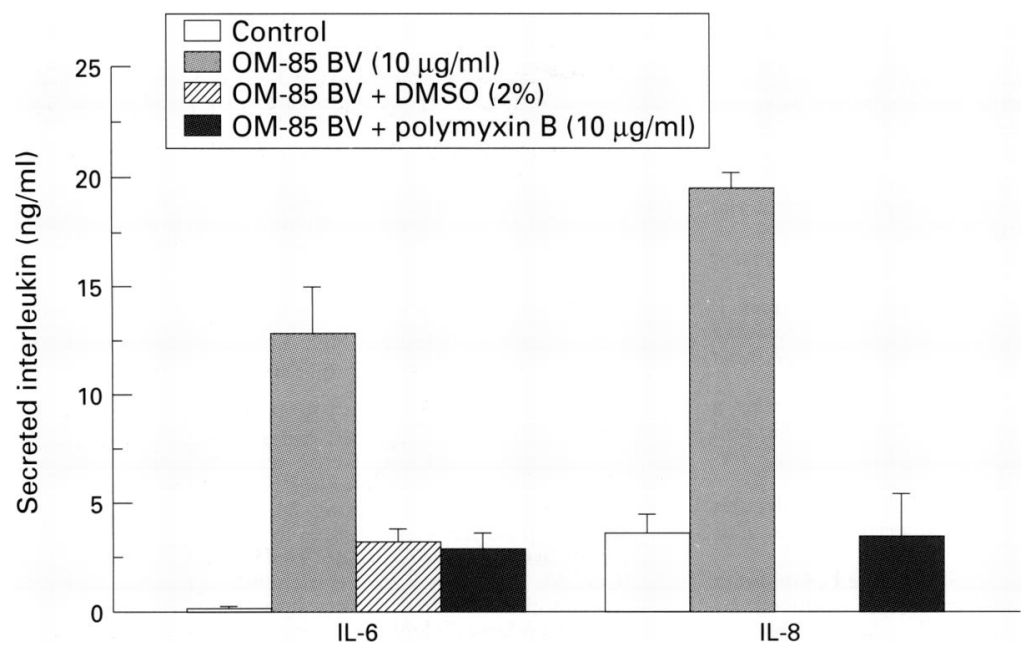

Figure 5 Effects of DMSO and polymyxin B on the OM-85 BV-induced secretion of IL-6 and IL-8 (at 12 hours) in human lung fibroblasts. Each bar represents the mean (SE) of five independent experiments.

dependent secretion of IL-6 and IL-8 was diminished in the presence of DMSO or polymyxin B (fig 5).

In order to rule out the possibility that contamination of OM-85 BV with lipopolysaccharide could be responsible for the effects on gene activation, cells were incubated with various concentrations of lipopolysaccharide that were equivalent to the lipopolysaccharide content determined in OM-85 BV. While lipopolysaccharide at concentrations of $1-10 \mathrm{ng} / \mathrm{ml}$ was found to induce transcription of cytokines, ${ }^{21}$ the amount of lipopolysaccharide contaminating OM-85 BV was $<1 \mathrm{pg} / \mathrm{mg}$. These concentrations were ineffective in inducing gene transcription ( $n=3$; data not shown). This clearly excludes unwarranted effects of the drug due to contamination with lipopolysaccharide.

\section{Discussion}

This present study shows that $\mathrm{OM}-85 \mathrm{BV}$ is capable of modulating the immune response by specifically inducing the expression of IL-6 and IL-8 genes in human lung fibroblasts. The mechanism of transcription achieved by OM$85 \mathrm{BV}$ involves the action of PKC, C-Fos and $\mathrm{C}-\mathrm{Fos} / \mathrm{SRE}$. Considering the various autocrine and paracrine effects of IL-6 and IL-8, our observation may explain some of the immunopharmacological effects induced by OM$85 \mathrm{BV}^{1-14}$ The fact that lipopolysaccharide was not detectable in the preparations of OM-85 BV used excluded unwarranted effects of lipopolysaccharide.

IL-6 can be synthesised and released by a variety of cells including $T$ and $B$ lymphocytes, monocyte/macrophages, endothelial cells, and fibroblasts. It is induced by a number of cytokines such as IL-1, platelet-derived growth factor and TNF, viruses, and endotoxin via transcriptional and post-transcriptional mechanisms. ${ }^{2130}$ In addition to its proinflammatory properties, IL-6 also displays some anti-inflammatory activities such as inhibition of macrophage proliferation, ${ }^{36}$ reduction of monocyte cytotoxicity, ${ }^{37}$ and inhibition of airway reactivity to metha- choline. ${ }^{38}$ Furthermore, IL-6 activates the ability of $B$ and $T$ cells to combat infection and tissue damage ${ }^{39}$ by modulating synthesis of specific antibodies, predominantly of the $\operatorname{IgA}$ and IgG class. ${ }^{31}$ The latter effect could well account for the ability of OM-85 BV to increase levels of $\operatorname{IgA}$ and IgG in patients suffering from various inflammatory diseases of the lung. ${ }^{56} \mathrm{It}$ also may explain the increased levels of IFN$\gamma^{6}$ and TNF- $\alpha^{9}$ in BAL fluid obtained from patients with chronic bronchitis after treatment with OM-85 BV.

It has recently been shown that IL-8 mediates accumulation and activation of polymorphonuclear leucocytes to endothelial cells after exposure to various inflammatory stimuli. $^{22}$ Expression of IL-8 on lung fibroblasts may augment adherence of immunocompetent cells during phagocytic challenge by local modulation of the extracellular matrix and support trafficking of macrophages between alveolar and interstitial compartments during inflammation. Enhanced chemotactic activity as well as increased activity of the oxidative metabolism and intracellular killing of bacteria due to increased expression of IL- $8^{23-2540}$ is paralleled by increased resistance to bacterial infections following treatment with OM-85 BV. ${ }^{14641}$

We have shown previously that OM-85 BV increases the concentration of intracellular free calcium via activation of phosphatidylinositol turnover. ${ }^{41}$ Induction of phosphatidylinositol turnover is usually paralleled by the activation of PKC. We have shown that inhibition of PKC, known to be essential for the action of $\mathrm{C}-\mathrm{Fos},{ }^{35}$ abolished OM-85 BV-induced gene transcription. This is consistent with data obtained in the presence of DMSO, known to suppress activation of C-Fos/SRE. ${ }^{35} \mathrm{C}-\mathrm{Fos} /$ SRE binding sites have been identified in the promoter regions of the c-fos gene, the IL- 6 and the IL- 8 genes. ${ }^{30}$ Taken together, our data provide evidence that the signalling cascade, stimulated by $\mathrm{OM}-85 \mathrm{BV}$, involves the action of PKC and C-Fos/SRE resulting in expression of the interleukins IL- 6 and IL- 8 which both have potential anti-inflammatory organ protective properties.

This project was financed by Alfried-Krupp-Stiftung, Essen, Federal Republic of Germany, and OM-Laboratories, CH-8102 Geneva, Switzerland.

1 Fontages R, Bottex C, Cristau B, Burckhart MF. Influence of a bacterial extract on antigen presentation and protection a bacterial extract on antigen presentation and protection against

2 Paupe J. Immunotherapy with an oral bacterial extract (OM$85 \mathrm{BV}$ ) for upper respiratory infections. Respiration 1991; 58:150-4.

3 Derenne JP, Delclaux B. Clinical experience with OM$85 \mathrm{BV}$ in upper and lower respiratory tract infections. Respiration 1992;59(Suppl 3):28-31.

4 Bessler WG, Kleine B, Martinez-Alonso C, Biesert L, Strecker K, Wiesmuller KH, et al. Biological activity of bacterial surface components: bacterial extracts and delined bacterial cell wall components as immunomodulators. Lung 1990;57(Suppl):707-15.

5 Palma-Carlos AG, Palma-Carlos ML. Effect of oral bacterial lysates on serum immunoglobulins. Allergy Immunol Paris 1989;21:354-6.

6 Emmerich B, Emslander HP, Pachmann K, Hallek M, Milatovich D, Busch R. Local immunity in patients with chronic bronchitis and the effects of a bacterial extract, broncho-vaxom, on T lymphocytes, macrophages, $\gamma$-interferon and secretory immunoglobulin A in bronchoalveolar lavage fluid and other variables. Respiration 1990; alveolar lavage fluid and other variables. Respiration 1990;
57:90-9. 
7 Mauel J. Stimulation of immunoprotective mechanisms by OM-85 BV. Respiration 1994;61(Suppl 1):8-15.

8 Moniuszko T, Rogalewska A, Chyrek-Borowska S. The effect of therapy with selected immunomodulators on interleukin-2 production by peripheral blood lymphocytes. Pneumonol Allergol Pol 1992;60(Suppl):120-1.

9 Wybran J, Libin M, Schandene L. Activation of natural killer cells and cytokine production in humans by bacterial extracts (OM-85 BV). Lung 1990;168(Suppl):720-5.

10 Mauel J. Macrophage activation by OM-85 BV. Respiration 1992;59(Suppl 3):14-8.

11 Mauel J, Pham TV, Kreis B, Corradin-Betz S, Bauer J, Evaluation of assay procedures measuring macrophage stimulation by immunomodulators in vitro. Dev Biol Stand 1992;77:71-7.

12 Mauel J, Pham TV, Kreis B, Bauer J. Stimulation by a bacterial extract (broncho-vaxom) of the metabolic and functional activities of murine macrophages. Int $7 \mathrm{Im}$ munopharmacol 1989;11:637-43.

13 Marchant A, Duchow J, Goldman M. Adhesion molecules in antibacterial defense: effects of bacterial extracts. Respiration 1992;59(Suppl 3):24-7.

14 Duchow J, Marchant A, Delville JP, Schandene L, Goldman $\mathrm{M}$. Upregulation of adhesion molecules induced by broncho-vaxom on phagocytic cells. Int $\mathcal{f}$ Immunopharmacol 1992;14:761-6.

15 Elias J, Trinchieri G, Bech J, Simon P, Sehgal P, May L, et al. Synergistic interaction of IL- 6 and IL-1 mediated the thymocyte stimulating activity produced by recombinant thymocyte stimulating activity produced by recombinant

IL-1 stimulated fibroblasts. F Immunol 1989;142:509-14.
16 Uyttenhove C, Coulie PG, Van Stick J. T cell growth and differentiation induced by interleukin-HP1/IL-6, the murine hybridoma/plasmacytoma growth factor. $\mathcal{f}$ Exp Med 1988;167:1417-27.

17 Okada S, Suda T, Suda J, Tokuyama N, Nagayoshi K, Miura Y, et al. Effects of interleukin-3, interleukin-6 and granulocyte colony stimulating factor on sorted murine splenic progenitor cells. Exp Hematol 1991;19:42-6.

18 Vercelli D, Jahara $H$, Arai $K$, Yokota T, Geha SR. Endogenous IL-6 plays an obligatory role in IL-4 dependent dogenous IL-6 plays an obligatory role in IL-4 dep

19 Denis $M$. Interleukin-6 in mouse hypersensitivity pneumonitis: changes in lung free cells following depletion of endogenous IL-6 or direct administration of IL-6. $₹$ Leukoc Biol 1992;52:197-201.

20 Tsan M, White J, DelVechio P, Shaffer JB. IL-6 enhances TNF $\alpha$ and IL- 1 induced increase in superoxide dismutase mRNA and $\mathrm{O}_{2}$ tolerance. Am 7 Physiol 1992;263:L 22-6.

21 Ulrich T, Yin S, Gno K, Eunhee SY, Remick D, Castillo J. Intratracheal injection of endotoxin and cytokines. $A m \mathcal{F}$ Physiol 1991;138:1097-101.

22 Schindler R, Manchilla J, Endres S, Ghorbani R, Clark SC, Dinarello CA. Correlation and interaction in the production of IL-6, IL-1 and TNF in human blood mononuclear cells: IL-6 suppresses IL-1 and TNF. Blood 1990; 75:40-7.

23 Nakamura H, Yushimura K, Jaffe HA, Crystal RG. Interleukin-8 gene expression in human bronchial epithelial cells. F Biol Chem 1991;266:19611-7.

24 Kasahara K, Strieter RM, Chensue SW, Standiford TJ, Kunkel SL. Mononuclear cell adherence induces neutrophil chemotatic factor/interleukin-8 gene expression. $\mathfrak{f}$ phil chemotatic factor/interle

25 Standiford TJ, Kunkel SL, Kasahara K, Milia MJ, Rolfe $\mathrm{MW}$, Strieter RM. Interleukin-8 gene expression from human alveolar macrophages: The role of adherence. $A m$ f Respir Cell Mol Biol 1991;5:579-85.

26 Matsushima K, Oppenheim JJ. Interleukin-8 and MCAF novel inflammatory cytokines inducible by IL-1 and TNF. Cytokine 1989;1:2-13.

27 Baggiolini M, Waltz A, Kunkel SL. Neutrophil-activating peptide-1/interleukin-8: a novel cytokine that activates neutrophils. I Clin Invest 1989;84:1045-9.

28 Schroder J. The monocyte-derived human neutrophil activating peptide (NAP/interleukin-8) stimulates human neutrophil arachidonate-5-lipoxygenase, but not the release of cellular arachidonate. $\mathcal{F} \operatorname{Exp}$ Med 1989;170:84763.

29 Sheppard MN, Harrison NK. Lung injury, inflammatory mediators, and fibroblast activation in fibrosing alveolitis. mediators, and fibroblast

30 Walther Z, May LT, Sehgal PB. Transcriptional regulations of the interferon $-\beta_{2} / \mathrm{B}$ cell differentiation factor $\mathrm{BSF}-2 /$ hepatocyte-stimulating factor gene in human fibroblast by other cytokines. F Immunol 1988;140:974-7.

31 Roth $M$, Solér $M$, Hornung $M$, Emmons LR, Stulz $P$, Perruchoud AP. Cell cultures from cryopreserved human lung tissue. Tissue Cell 1992;24:455-9.

32 Roth M, Emmons LR, Perruchoud AP, Block LH. Expression of the low density lipoprotein receptor and 3 hydroxy-3-methylglutaryl coenzyme A reductase genes are stimulated by recombinant platelet-derived growths factor isomers. Proc Natl Acad Sci USA 1991;88:1888-92.

33 Ziesche $R$, Roth M, Papakonstantinou, Nauck M, Hör WH, Kashgarian M, et al. A granulocyte inhibitory protein overexpressed in chronic renal disease regulates expression of interleukin-6 and interleukin-8. Proc Natl Acad Sci USA 1994;91:301-5.

34 Srinivas S, Sironmani TA, Shanmugan G. Dimethyl sulf oxide inhibits the expression of early growth-response oxide inhibits the expression of early growth-response genes and arrests

35 Lewin I, Nechushtan H, Ke Q, Razin E. Regulation of AP1 expression and activity in antigen-stimulated mast cells: the role played by protein kinase $\mathrm{C}$ and the possible involvement of Fos interacting protein. Blood 1993;82. 3745-51

36 Reidy $M$, Steward C. Inhibitory role of interleukin-6 in macrophage proliferation. F Leukoc Biol 1992;52:125-7.

37 Aderkan D, Jumming LE, Vilcek J. IL-6 inhibits lipopolysaccharide induced tumor necrosis factor production in cultured human monocyte, U937 cells and in mice. Immunol 1989;143:3517-23.

38 DiCosimo BF, Geba GP, Picarella D, Elias JA, Rankin JA, Stripp BR, et al. Airway epithelial cell expression of interleukin-6 in transgenic mice. $f$ Clin Invest 1994;94:2028 35.

39 Kohase M, May LT, Tamm I, Vilcek J, Sehgal PB. A cytokine network in human diploid fibroblasts: interactions of $\beta$-interferons, tumor necrosis factor, plateletderived growth factor, and interleukin-1. Mol Cell Biol 1987;7:273-80.

40 Strieter RM, Koch AE, Antony VB, Fick RB, Standiford TJ, Kunkel SL. The immunopathology of chemotactic TJ, Kunkel SL. The immunopathology of chemotactic cytokines: the role of interleukin-8 and monocyte 183-97.

41 Nauck M, Matthys H, Emmons LR, Perruchoud AP, Reichel $\mathrm{H}$, Pfleger $\mathrm{S}$, et al. The immunomodulators bronchovaxom and uro-vaxom stimulate the bacterial killing and oxidative metabolism of polymorphonuclear leukocytes by the activation of phosphatidylinositol turnover. Int $\mathcal{F} E x p$ Clin Chemother 1992;4:1-11. 